\title{
DECENTRALIZATION'S EFFECTS ON EDUCATIONAL OUTCOMES IN BOLIVIA AND COLOMBIA ${ }^{\S}$
}

\author{
Jean-Paul Faguet * \\ Fabio Sánchez **
}

DEDPS 47

March 2006

The Suntory Centre

Suntory and Toyota International Centres for Economics and Related Disciplines

London School of Economics and Political Science

Houghton Street

London WC2A $2 \mathrm{AE}$

Tel: (020) 79556674

* $\quad$ Lecturer in the Political Economy of Development, Development Studies Institute and STICERD, London School of Economics, Houghton Street, London WC2A 2AE, +44-20-7955-6435 (o), 7955-6844 (f), j.p.faguet@lse.ac.uk (contact author)

** Professor of Economics and Director of CEDE, Universidad de los Andes, Carrera 1 № 18A-70, Bloque C, Bogotá, Colombia

\footnotetext{
$\S$ This research was financed by the World Bank Research Committee. We are very grateful to Patricia Rincón, Camila Torrente and Victoria Soto for expert research assistance, and to Krister Andersson, Tim Besley, Teddy Brett, Juan Pablo Jiménez, Stuti Khemani, Asim Khwaja, Luis Felipe López, Mauricio Merino, Dilip Mookherjee, Anja Nygren, Daniel Treisman, four anonymous referees and seminar participants at the IPD Decentralization Task Force, CSP-Delhi and UNDP-Mexico meetings for their thoughtful suggestions. All remaining errors are ours.
} 


\begin{abstract}
The effects of decentralization on public sector outputs is much debated but little agreed upon. This paper compares the remarkable case of Bolivia with the more complex case of Colombia to explore decentralization's effects on public education outcomes. In Colombia, decentralization of education finance improved enrollment rates in public schools. In Bolivia, decentralization made government more responsive by re-directing public investment to areas of greatest need. In both countries, investment shifted from infrastructure to primary social services. In both, it was the behavior of smaller, poorer, more rural municipalities that drove these changes.
\end{abstract}

Keywords: decentralization, education, public investment, Bolivia, Colombia, local government

\title{
Contents
}

1. Introduction

2. The Bolivian and Colombian Decentralization Programs

3. Decentralization

4. Decentralization and Public Investment - An Overview

5. Decentralization's Effects - More Rigorous Evidence

6. Conclusions

Notes

References 


\section{Development Economics Discussion Paper Series}

This series is published by the Economic Organisation and Public Policy Programme (EOPP) located within the Suntory and Toyota International Centres for Economics and Related Disciplines (STICERD) at the London School of Economics and Political Science. The programme was established in October 1998 as a successor to the Development Economics Research Programme. The work of the programme is mainly in the fields of development economics, public economics and political economy. It is directed by Tim Besley, Oriana Bandiera, Robin Burgess, Maitreesh Ghatak and Andrea Prat. Further details about the programme and its work can be viewed on our web site at http://sticerd.lse.ac.uk/research/eopp.

Our Discussion Paper series is available free of charge. To subscribe to DEDPS, please contact Leila Alberici on:

$\begin{array}{ll}\text { Telephone: } & \text { UK+20 } 79556674 \\ \text { Fax: } & \text { UK+20 79556951 } \\ \text { Email: } & \text { l.alberici@1se.ac.uk } \\ \text { Web site: } & \text { http://sticerd.lse.ac.uk/dedps }\end{array}$

Tim Besley

Oriana Bandiera

Robin Burgess

Maitreesh Ghatak

Andrea Prat

(C) The authors. All rights reserved. Short sections of text, not to exceed two paragraphs, may be quoted without explicit permission provided that full credit, including (C) notice, is given to the source. 


\section{INTRODUCTION}

Over the past few decades decentralization has become one of the most debated policy issues throughout both developing and developed worlds. It is seen as central to the development efforts of countries as far afield as Chile, China, Guatemala and Nepal. And in the multiple guises of subsidiarity, devolution and federalism it is also squarely in the foreground of policy discourse in the EU, UK and US. But surprisingly, there is little agreement in the empirical literature on the effects of decentralization on a number of important policy goals. Advocates (e.g. Olowu and Wunsch 1990, Putnam 1993, World Bank 1994, UNDP 1993) argue that decentralization can make government more responsive to the governed by "tailoring levels of consumption to the preferences of smaller, more homogeneous groups" (Wallis and Oates 1988, 5). Critics (e.g. Crook and Sverrisson 1999, Prud'homme 1995, Samoff 1990, Smith 1985, Tanzi 1995) dispute this, arguing that local governments are too susceptible to elite capture, too lacking in technical, human and financial resources, and too corrupt to produce a heterogeneous range of public services that respond efficiently to local demand. And their profligacy is likely to endanger macroeconomic stability. But neither side is able to substantiate its arguments convincingly with empirical evidence.

Much of the debate has taken place in these pages, similarly without resolution.

Of 24 articles on decentralization, local government and responsiveness published in World Development since 1997, 11 report broadly positive results, and 13 are negative.

Fiszbein (1997), Shankar and Shah (2003), Oliveira (2002) and Parry (1997) are amongst the most enthusiastic, finding that decentralization can spur capacity building in local government (Colombia), decrease levels of regional inequality through political 
competition (a sample of 26 countries), boost the creation and administration of protected areas (Bahia, Brazil), and improve educational outcomes (Chile), respectively. Rowland (2001) and Blair (2000) find that decentralization improved the quality of democratic governance achieved in both large cities and small towns. And Petro (2001) finds that local government played a pivotal role in raising levels of social capital in Novgorod, Russia by establishing common social values and priorities for the community. Other authors, such as Andersson (2004), Larson (2002), McCarthy (2004) and Nygren (2005), are more cautious, arguing broadly that decentralization is a complex, problematic phenomenon, but may ultimately have positive effects on local welfare.

Amongst skeptics, some of the most striking are Ellis and Kutengule (2003), Ellis and Mdoe (2003) and Ellis and Bahiigwa (2003), who find that decentralization will likely depress growth and rural livelihoods by facilitating the creation of new business licenses and taxes that stifle private enterprise (Malawi), and propagate rent-seeking behavior down to the district and lower levels, so becoming "part of the problem of rural poverty, not part of the solution"" (Tanzania and Uganda), respectively. Similarly, Bahiigwa, Rigby and Woodhouse (2005) and Francis and James (2003) show that decentralization in Uganda has not led to independent, accountable local governments, but rather to their capture by local elites, and hence to the failure of decentralization as a tool for poverty reduction. Porter (2002) agrees for Sub-Saharan Africa more generally. Regarding the environment, Woodhouse (2003) predicts that decentralization will fail to improve access of the poor to natural resources, or reduce ecological damage. Casson and Obidzinski (2002) go further, reporting that decentralization in Indonesia has spurred depredatory logging by creating bureaucratic actors with a stake in its proliferation. The cross-country evidence of Martinez-Vazquez and McNab (2003) is similarly unhopeful, 
showing that we don't know empirically whether decentralization affects growth directly or indirectly, and have no clear theoretical grounds for predicting a relationship either way. Worse, de Mello's (2000) study of 30 countries predicts that failures of intergovernmental fiscal coordination will lead to chronic deficits and, eventually, macroeconomic instability. The papers of Sundar (2001), Thun (2004) and Wiggins, Marfo and Anchirinah (2004) offer more cautious, nuanced arguments, that are on the whole skeptical about the possibility of beneficial change through decentralization.

The larger literature is similarly inconclusive. Amongst studies of Latin America, Campbell (2001) highlights the extraordinary scope of authority and resources that have been decentralized throughout the region, and argues that this "quiet revolution" has generated a new model of governance based on innovative, capable leadership, high popular participation, and a new implicit contract governing local taxation. But Montero and Samuels (2004) argue that the political motives of reformers often combine with expost vertical imbalances to make decentralization bad in terms of elite capture, regional inequality and macroeconomic stability. Rodríguez-Posé and Gill (2004) elaborate further on the tension between inequality and stability for the case of Brazil, while Eskeland and Filmer (2002) find econometric evidence that decentralization did lead to improvements in Argentine educational achievement scores.

Amongst the broadest international surveys: Rondinelli, Cheema and Nellis (1983) note that decentralization has seldom, if ever, lived up to expectations. Most developing countries implementing decentralization experienced serious administrative problems. Although few comprehensive evaluations of the benefits and costs of decentralization efforts have been conducted, those that were attempted indicate limited success in some countries but not others. A decade and a half later, surveys by Piriou- 
Sall (1998), Manor (1999) and Smoke (2001) are slightly more positive, but with caveats about the strength of the evidence in decentralization's favor. Manor ends his study with the judgment that "while decentralization ...is no panacea, it has many virtues and is worth pursuing", after noting that the evidence, though extensive, is still incomplete. Smoke finds the evidence mixed and anecdotal, and asks whether there is empirical justification for pursuing decentralization at all. More recently, in a review of 56 studies published since the late-1990s, Shah, Thompson and Zou (2004) find evidence that decentralization has in some cases improved, and in others worsened, service delivery, corruption, macroeconomic stability, and growth across a large range of countries. The lack of progress is striking.

This paper examines decentralization's effects on educational outcomes in Bolivia and Colombia. We first examine how decentralization changed investment flows across sectors, and across space, in both countries. We then focus much more closely on education outputs, which a remarkable range of analysts agree is a top priority for developing countries. Our quantitative analysis is unusual in that the bulk of the empirical literature can be grouped into two broad categories: (1) small-N studies that link decentralization with real outcomes of interest (e.g. Parry 1997), and (2) large-N studies that link decentralization to input or process-type variables, as opposed to real outcomes (e.g. Faguet 2004). Systematic evidence for a link between decentralization and real outcome variables are remarkably few and far between. This paper examines just such a link for Colombia, and gets as close as the data allow for Bolivia.

Why focus on these two countries in particular? There are four reasons: (i) in both cases, decentralization was advocated as a remedy for a state whose unresponsiveness to citizens' needs fed serious internal tensions, including armed 
insurgency in Colombia; (ii) in both cases, decentralizing reforms were pursued in a vigorous and sustained manner; (iii) the broad geographic, institutional and historical similarities these countries share limit problems of data comparability and interpretation; and (iv) although their internal ructions have attracted much international attention recently, both are relatively underrepresented in the literature. Bolivia is particularly deserving of study because reform there consisted of a large change in policy at a discrete point in time, thus rendering it a sort of natural experiment. Colombia is more relevant for many middle-income countries because of its greater wealth, level of development, and relatively high state capacity. And its more complex, multifaceted reform process is more typical of decentralizations around the world. To our knowledge, this is the first comparative study of decentralization in Bolivia and Colombia.

Decentralization is henceforth defined as the devolution by central (i.e. national) government of specific functions, with all of the administrative, political and economic attributes that these entail, to democratic local (i.e. municipal) governments which are independent of the center within a legally delimited geographic and functional domain. We mostly ignore intermediate levels of government (departments) for two reasons: (i) Bolivia decentralized directly to municipalities, by-passing departments entirely at first, and only recently making prefects elected; Colombia did not, but focusing on municipalities facilitates the country comparison. And (ii) the simplicity of the definition thus facilitated aids analytical clarity.

The rest of the paper is organized as follows. Section 2 reviews the Bolivian and Colombian decentralization programs, focusing on their legal and budgetary aspects. Section 3 examines decentralization's effects on public investment flows in both countries. Section 4 presents our quantitative methodology. Section 5 examines whether 
decentralization made education investment more responsive to local needs in Bolivia, and whether it increased school enrollment in Colombia, with detailed econometric evidence. And section 6 concludes.

\section{THE BOLIVIAN AND COLOMBIAN DECENTRALIZATION PROGRAMS}

\section{(a) Popular participation in Bolivia}

On the eve of revolution, Bolivia was a poor, backward country with extreme levels of inequality, presided over by a "typical racist state in which the non-Spanish speaking indigenous peasantry was controlled by a small, Spanish speaking white elite, [their power] based ultimately on violence more than consensus or any social pact" (Klein 1993, 237; our translation). The nationalist revolution of 1952, which expropriated the "commanding heights" of the economy, land and mines, launched Bolivia on the road to one of the most centralized state structures in the region. The government embarked upon a state-led modernization strategy in which public corporations and regional governments initiated a concerted drive to break down provincial fiefdoms, transform existing social relations, and create a modern, industrial, egalitarian society (Dunkerley 1984). To this end the President directly appointed Prefects, who in turn designated entire regional governments and associated dependencies, forming a national chain of cascading authority emanating from the Palacio Quemado in La Paz.

The intellectual trends of the 1950s-1970s - Dependencia theory, Import Substitution Industrialization, and Developmentalism - contributed to the centralizing tendency, as did the military governments which overthrew elected administrations with 
increasing frequency from the 1960s on (Klein 1993). With political power so little dispersed, there was little point in establishing the legal and political instruments of local governance. As a result, beyond the nine regional capitals (including La Paz) and an additional 25-30 cities, local government existed in Bolivia at best in name, as an honorary and ceremonial institution devoid of administrative capability and starved for funds. And in most of the country it did not exist at all.

Although the 1994 reform was sprung on an unsuspecting nation, the concept of decentralization was by no means new. For more than 30 years a decentralization debate focused on Bolivia's nine departments ebbed and flowed politically - at times taking on burning importance, other times all but forgotten. The issue became caught up in the country's centrifugal tensions, as regional elites in Santa Cruz and Tarija consciously manipulated the threat of secession to Brazil and Argentina respectively - with which each is economically more integrated than $\mathrm{La} \mathrm{Paz}$ - to extract resources from the center. The Bolivian paradox of a highly centralized but weak state, and a socially diverse population with weak national identity, meant that such threats were taken seriously by the political class, which blocked all moves to devolve more power and authority to Bolivia's regions.

So what spurred the change of tack? and why then? Two factors stand out. The less important one arises from Bolivia's failure to achieve sustained, healthy growth despite wrenching economic reform overseen by the IMF and World Bank. Fifteen years of near-zero per capita economic growth sapped the credibility of the state and fomented social unrest. The new Movimiento Nacionalista Revolucionario (MNR) administration of Pres. Sánchez de Lozada saw the structure of government itself as an impediment to growth. Decentralization was an attempt to deepen structural reform in order to make the 
state more efficient and responsive to the population, and so regain its legitimacy in the voters' eyes.

The more important factor arises from the rise of ethnically-based, populist politics in the 1980s, which undercut the MNR's traditional dominance of the rural vote, and posed a serious challenge to its (self-declared) role as the "natural party of government". This rural dominance was itself born out of the MNR's agrarian reforms of the 1952-3 revolution. Hence a party with a tradition of radical reform, which found itself in secular decline, sought a second, re-defining moment. In a typically bold move, it sought to reorganize government, re-cast the relationship between citizens and the state, and so win back the loyalty of Bolivians living outside major cities. To a very important extent, decentralization was a gambit to capture rural voters for at least another generation. $^{2}$

Against this background, the Bolivian decentralization reform was announced in 1994. The Law of Popular Participation, developed almost in secret by a small number of technocrats (Tuchschneider 1997), was announced to the nation to general surprise, then ridicule, then determined opposition from large parts of society. ${ }^{3}$ It is notable that opposition to the law, which was fierce for a few months, came principally from the teachers' union, NGOs and other social actors, and not from political parties. Judged by their public declarations, this opposition was an incoherent mix of accusations and fears that denoted a deep suspicion of the government's motives, and not a careful reading of the law. The lack of opposition from parties can largely be attributed to the sweeping reforms that were being enacted by the MNR government at the same time as decentralization. With privatization of the main state enterprises, education reform, and a comprehensive restructuring of the executive branch all being pushed at once, 
decentralization was relegated to the second tier of political parties' concerns. The opposition focused its attention elsewhere, and it never became a fighting point.

First made public in January of that year, the law was promulgated by Congress in April and implemented from July. The scale of the change in resource flows and political power that it brought about were enormous. The core of the law consists of four points (Secretaría Nacional de Participación Popular, 1994):

1. Resource Allocation. Funds devolved to municipalities doubled to 20 percent of all national tax revenue. More importantly, allocation amongst municipalities switched from unsystematic, highly political criteria to a strict per capita basis.

2. Responsibility for Public Services. Ownership of local infrastructure in education, health, irrigation, roads, sports and culture was given to municipalities, with the concomitant responsibility to maintain, equip and administer these facilities, and invest in new ones.

3. Oversight Committees (Comités de Vigilancia) were established to provide an alternative channel for representing popular demand in the policy-making process. Composed of representatives from local, grass-roots groups, these bodies propose projects and oversee municipal expenditure. Their ability to have disbursements of Popular Participation funds suspended if they find funds are being misused or stolen can paralyze local government, and gives them real power.

4. Municipalization. Existing municipalities were expanded to include suburbs and surrounding rural areas, and 198 new municipalities (out of some 315 in all) were created. 
This was followed by the Law of Decentralized Administration (1995) and the Law of Municipalities (1999), which further defined the municipal mandate and located it in a broader governmental architecture.

The change in local affairs that these measures catalyzed is immense. Before reform local government was absent throughout the vast majority of Bolivian territory, and the broader state present at most in the form of a military garrison, schoolhouse or health post, each reporting to its respective ministry. After reform, elected local governments sprouted throughout the land. This is reflected in resources flows between center and periphery. Before decentralization Bolivia's three main cities took $86 \%$ of all devolved funds, while the remaining 308 municipalities divided amongst them a mere $14 \%$. After decentralization the shares reversed to $27 \%$ and $73 \%$ respectively. The per capita criterion resulted in a massive shift of resources to previously neglected areas. Amongst smaller, poorer rural districts, resource increases of 50,000 - 100,000 percent were quite common.

\section{(b) The decentralization process in Colombia}

Like Bolivia, Colombia was traditionally a highly centralized country, with mayors and governors directly named by central government. Governors, in particular, were the President's hombres de confianza, and carried out his will in the regions. But unlike Bolivia’s “big bang” reform, decentralization in Colombia developed over years as a much more gradual, incremental process. Ceballos and Hoyos (2004) identify three broad phases:

Phase 1 began in the late 1970s and early 1980s, and included a number of fiscal measures aimed at strengthening municipal finances. Most important of these were Law 
14 of 1983 and Law 12 of 1986, which assigned to municipalities increased powers of tax collection, including especially sales tax, and established parameters for the investment of these funds.

Phase 2, which began in the mid-1980s, was more concerned with political and administrative matters. Amongst the most important of these measures was Law 11 of 1986, which regulated the popular election of mayors and sought to promote popular participation in local public decision-making via Juntas Administradoras Locales, amongst others. Reforms enshrined in the 1991 constitution, such as citizens' initiatives, municipal planning councils, open cabildos, the ability to revoke mayoral mandates, referenda, and popular consultations, further deepened political decentralization. The 1991 constitution also established the popular election of governors.

Phase 3 consisted of a number of laws that regulated the new constitution, and other fiscal and administrative reforms of the period These laws assigned greater responsibility to municipalities for the provision of public services and social investment, and provided additional resources for the same by increasing central government transfers to local governments significantly. The laws mandate that the bulk of transferred funds should be spent on education and health, with little discretion left to local governments. Automatic transfers to regional governments rose from about $20 \%$ to over $40 \%$ of total government spending, placing Colombia first in the region amongst countries with a unitary state, and third overall behind the two big federal countries, Brazil and Argentina (Alesina et al., 2000).

The aggregate effect of two decades of political and fiscal reforms was a large increase in the authority and operational independence of Colombia's municipal governments, accompanied by a huge rise in the resources they controlled. 
Municipalities were allowed to raise and spend significant sums of taxes, central-to-local government transfers increase more than three fold, ${ }^{4}$ and municipal governments were permitted to issue public debt. Overall municipal expenditures and investments rose from $2.8 \%$ to $8.3 \%$ of GDP, as detailed in figure 1 . This rise was due entirely to increased investment, while running costs remained stable over the period. ${ }^{5}$

\section{Figure 1}

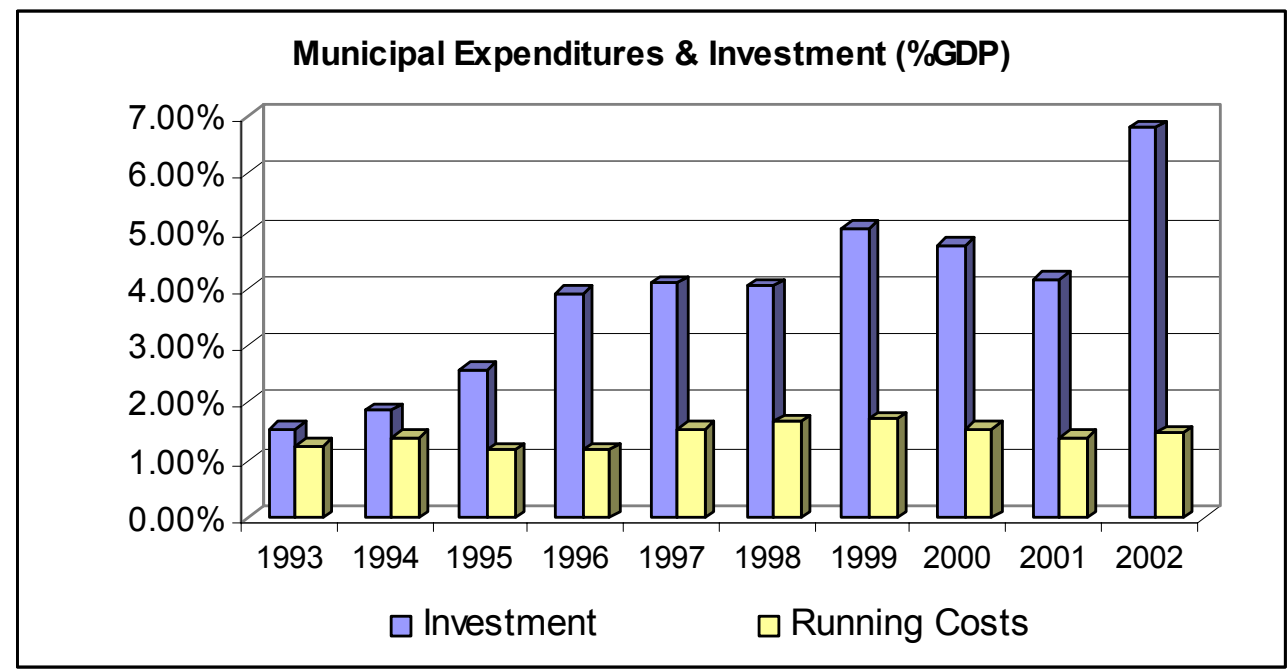

Source: Original calculations; database compiled from official Colombian sources.

What drove decentralization in Colombia? As befits a much longer and more elaborate process, we cannot limit the motivating factors of reform to a few discrete goals. Ceballos and Hoyos group the many reasons into two categories. The first of these is the challenge of political instability. Colombia is a violent country - much more so than Bolivia - with a long history of civil conflict, armed rebellion, persistently high levels of "common" crime, and the use of violence as an explicit tool of political mobilization. The late 1970s saw levels of violence rise again as the internal conflict intensified. At the same time, social protests and pressures from regional groups multiplied, linked to the central state's inability to meet demands for social services and 
public investment. Secondly, the political hegemony over the instruments of the state of the traditional Liberal and Conservative parties began to be seen more and more as a liability - less the solution to a previous round of civil violence (La Violencia) and more a cause of the next one. Colombians from across the political spectrum became convinced that the inability of the state to respond to society's demands - and its outright absence in many areas (the "internal frontier"), combined with the waning legitimacy of an arbitrarily restricted democracy, ${ }^{6}$ were leading to public sector inefficiencies, civic discontent, and ultimately armed violence.

Thus from the start decentralization in Colombia was a multi-faceted tool designed to serve a combination of purposes particular to Colombia's troubled democracy. Through it, policy elites sought to increase the levels of electoral and citizen participation within the existing institutional framework. They sought to open the political system via popular elections at the regional and local levels, where they hoped new political movements would eventually break the liberal-conservative hegemony over the resources of the state. In Colombia's largest cities this has indeed been the case; elsewhere evidence is mixed (see Ceballos and Hoyos 2004).

\section{DECENTRALIZATION AND PUBLIC INVESTMENT - AN OVERVIEW}

\section{(a) Bolivia}

The extent of the change decentralization brought about in Bolivia is perhaps best appreciated by examining how it changed the composition of municipal public investment. Figure 2 compares investment by sector during the final three years under centralized rule (1991-3; dark bars) with decentralized investment during the first three 
years after (1994-6; light bars). To better compare like with like, we omit sectors such as hydrocarbons, mining and national defense, which are not well suited to local government action (and remained the responsibility of central government in Bolivia). ${ }^{7}$ The differences are nonetheless large. In the years leading up to reform, central government invested most in transport, energy and multisectoral, ${ }^{8}$ which together accounted for $65 \%$ of public investment during 1991-3. After decentralization, local governments invest most heavily in education, urban development, and water \& sanitation, together accounting for $79 \%$ of municipal investment. Of the top three sectors in both cases, accounting for the great majority of total investment, central and local government have not one in common. The evidence implies that local and central government have very different investment priorities. Decentralizing power and resources to municipal governments shifted public investment away from economic production and infrastructure, and into social services and human capital formation.

\section{Figure 2}

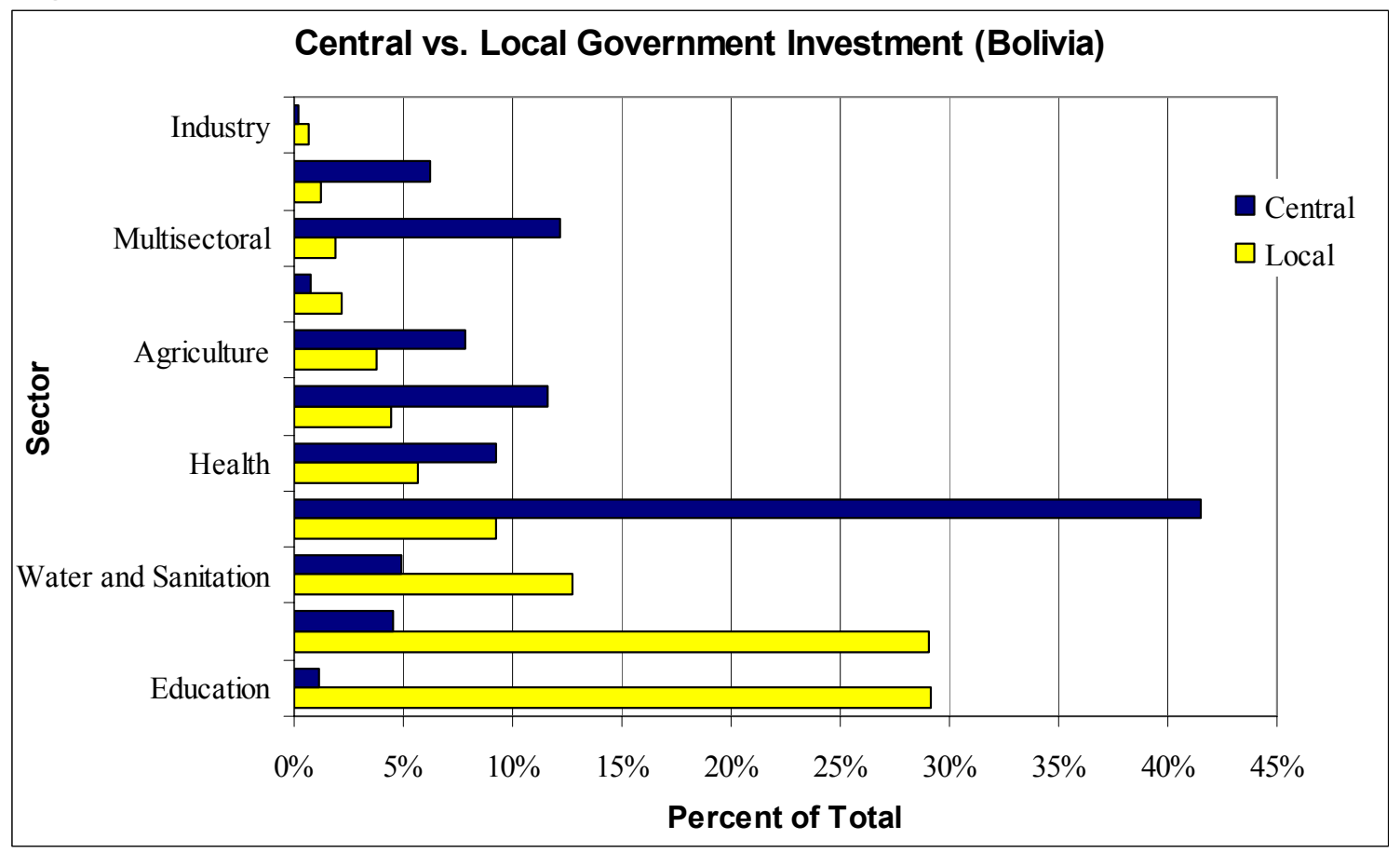

Source: Original calculations; database compiled from official Bolivian sources. 
Consider also how investment was distributed geographically among Bolivia's municipalities before and after decentralization. Figure 3 shows quasi-histograms of total investment in all of Bolivia's municipalities in per-capita terms, again for the last three years under centralized rule vs. the first three years of decentralization. The vertical bars measure the proportion of Bolivia's municipalities that received investments in the given ranges. The chart shows that central government invested very unequally, with almost half of all municipalities receiving nothing while a small number received huge sums (over Bs.50,000/capita in one case), and the mean well outside the modal range. Under local government, by contrast, investment was much more equal: No districts received zero and none received more than Bs.620/capita, the modal range contains the mean, and the standard deviation is $97 \%$ lower than central government's. Closer inspection of the leftmost column ("=0") in the left-hand chart below reveals that it is composed overwhelmingly of the smallest, poorest, most rural districts. These are the municipalities that were most affected by decentralization.

Figure 3: Distribution of Central and Local Government Investment by Amount
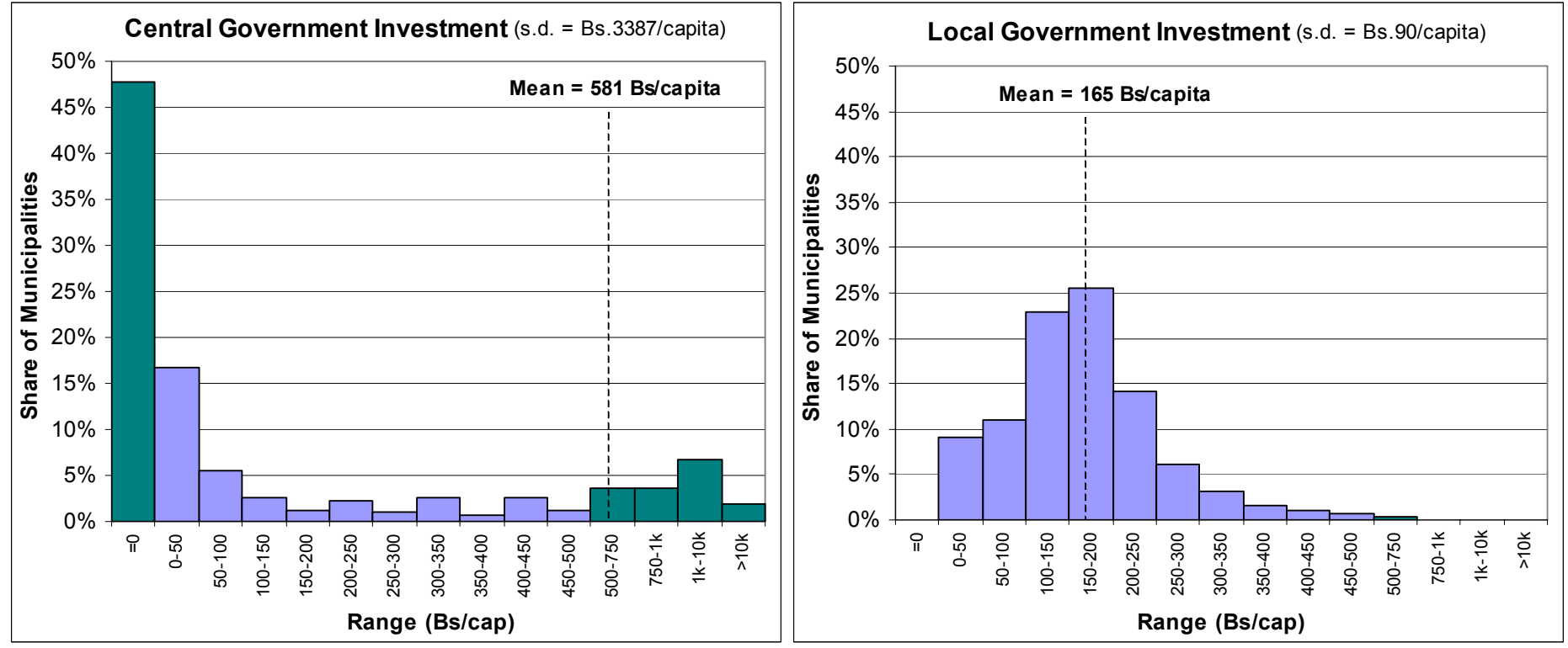

Source: Author's calculations. Note irregular outer intervals. 
So decentralization seems to have changed the sectoral uses of investment and its distribution across space. Did its effects run any deeper? Figure 4 plots education investment under central and local government (three-year totals again) vs. local illiteracy rates for all of Bolivia's municipalities. We use the illiteracy rate as a proxy for a district's need for more education investment. ${ }^{9}$ The most striking thing about the lefthand plot is how few nonzero observations there are before decentralization - only $15 \%$ of districts recorded any investment at all under central government. The regression line is negative with a modest slope, and significant at the $11 \%$ level. Contrast that with decentralized government, where $97 \%$ of districts invested in the sector, amounts are larger across the board, and the regression line on illiteracy is positively sloped and significant at the $0.1 \%$ level. Decentralization appears to have transformed education policy from one that ignored most municipalities in order to focus resources in those bestprovided, to one that invested essentially everywhere, focusing resources where existing levels of education were worst. Section 5 looks at this question much more rigorously.

Figure 4: Education Investment vs. Illiteracy
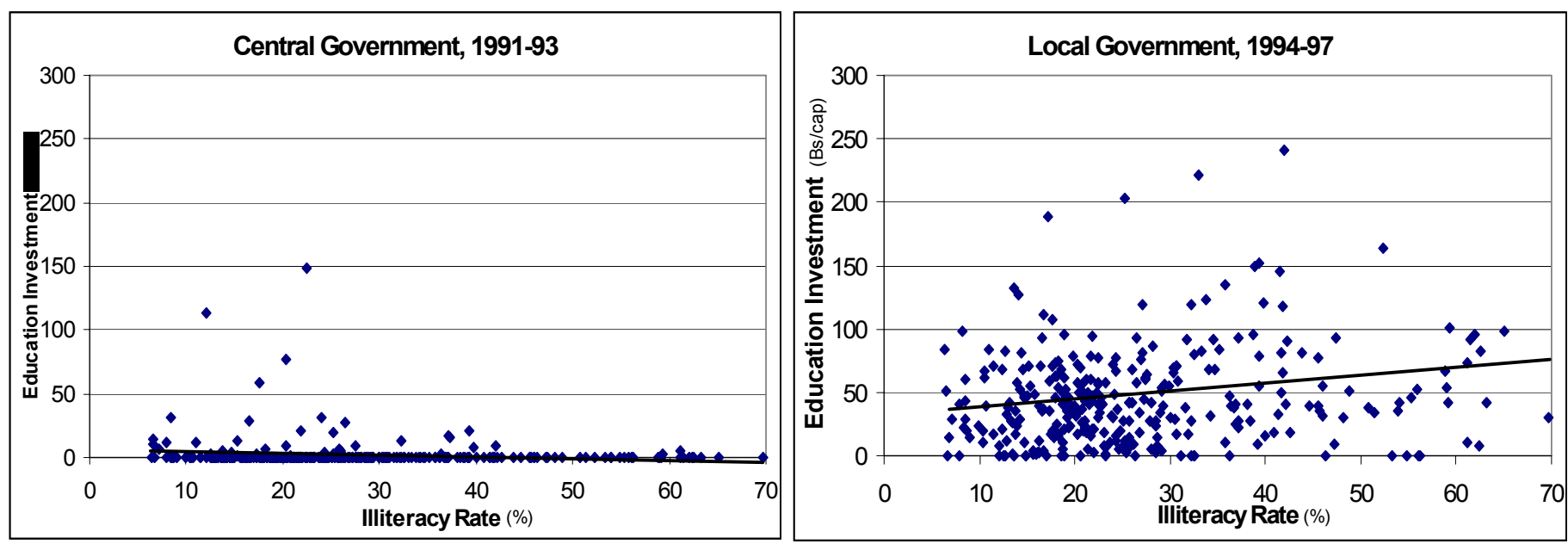

Source: Original calculations; database compiled from official Bolivian sources 


\section{(b) Colombia}

Detailed municipal-level expenditure and investment data are available for Colombia only from 1994. Hence we cannot examine investment priorities under a relatively "pure" centralized regime (i.e. which ended in the mid-1970s), as we did for Bolivia. But the characteristics of Colombia's reform process, marked by gradualism and long-term change, make this less of a problem. As discussed above, a number of key decentralizing mechanisms, such as citizens' initiatives, referenda, mayoral recall, and increased resource transfers, were only put in place with the 1991 constitutional reform and accompanying regulations. These transferred resources and authority to municipalities gradually over time. Hence we may consider that the outlines of Colombia's decentralization "package" became fully clear only in 1992-93, setting off a process that deepened thereafter. Indeed, the empirical measures of decentralization that we use below all show monotonically increasing levels of decentralization throughout the period 19942004. Hence hereafter we treat 1993-94 as years with relatively high centralization, and 2003-04 as years with relatively high decentralization.

How did decentralization affect public investment patterns? In order to examine the investment priorities of central vs. local government as closely as we can, figure 5 compares central government investment in 1994 with local government investment of own resources (i.e. local taxes and charges) in $2003 .{ }^{10}$ As for Bolivia, the differences are large. Central government's largest category, at 38\% of the total, is infrastructure, whereas local government's largest is health, followed by education, which together comprise $81 \%$ of the local investment budget. The broader pattern of dark and light bars in figure 5 shows a clear shift in public sector priorities, and resources, away from 
infrastructure and industry and commerce, into health, education, and water and sanitation. The similarity with Bolivia is striking.

\section{Figure 5}

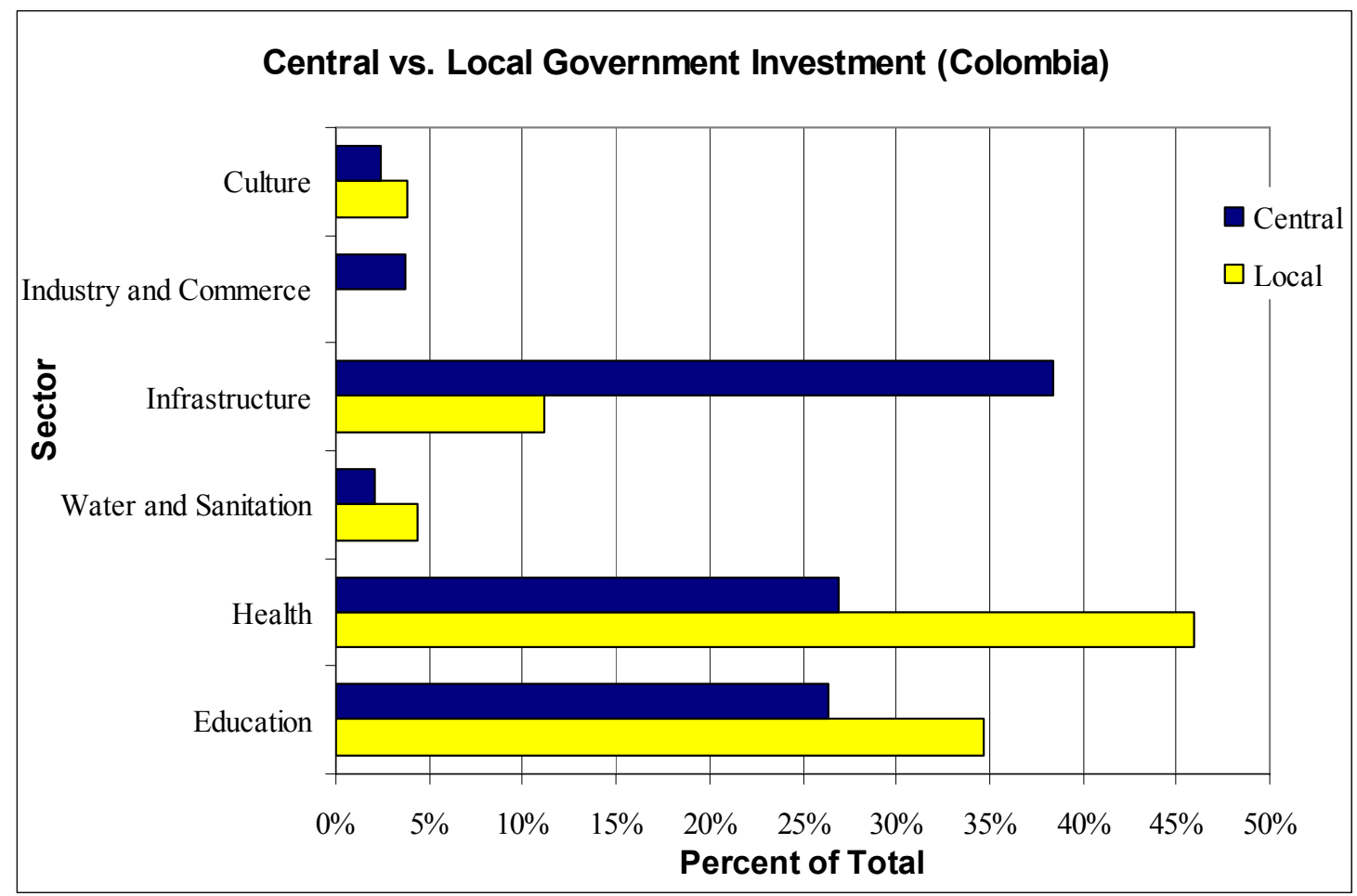

Source: Original calculations; database compiled from official Colombian sources

With respect to the geographic distribution of investment, figure 6 provides histograms of the public investment in Colombia's municipalities in 1994 vs. 2003. Amounts are given in constant 2002 pesos per capita, again divided by source between central and local governments. As decentralization deepened, both central and local investment became more dispersed, especially in the upper tails. This implies increasing inequality in investment, with some municipalities receiving much greater per capita sums than the norm. Both means rose significantly over the period, by $53 \%$ in the case of central government, and $105 \%$ for local government, implying that districts benefited quite significantly from increasing levels of investment by both central and local 
governments. Standard deviations were quite similar for central and local government in each period. The charts show clearly that the major differences are between 1994 and 2003, and not between center and periphery.

\section{Figure 6: Distribution of Central and Local Government Investment by Amount}
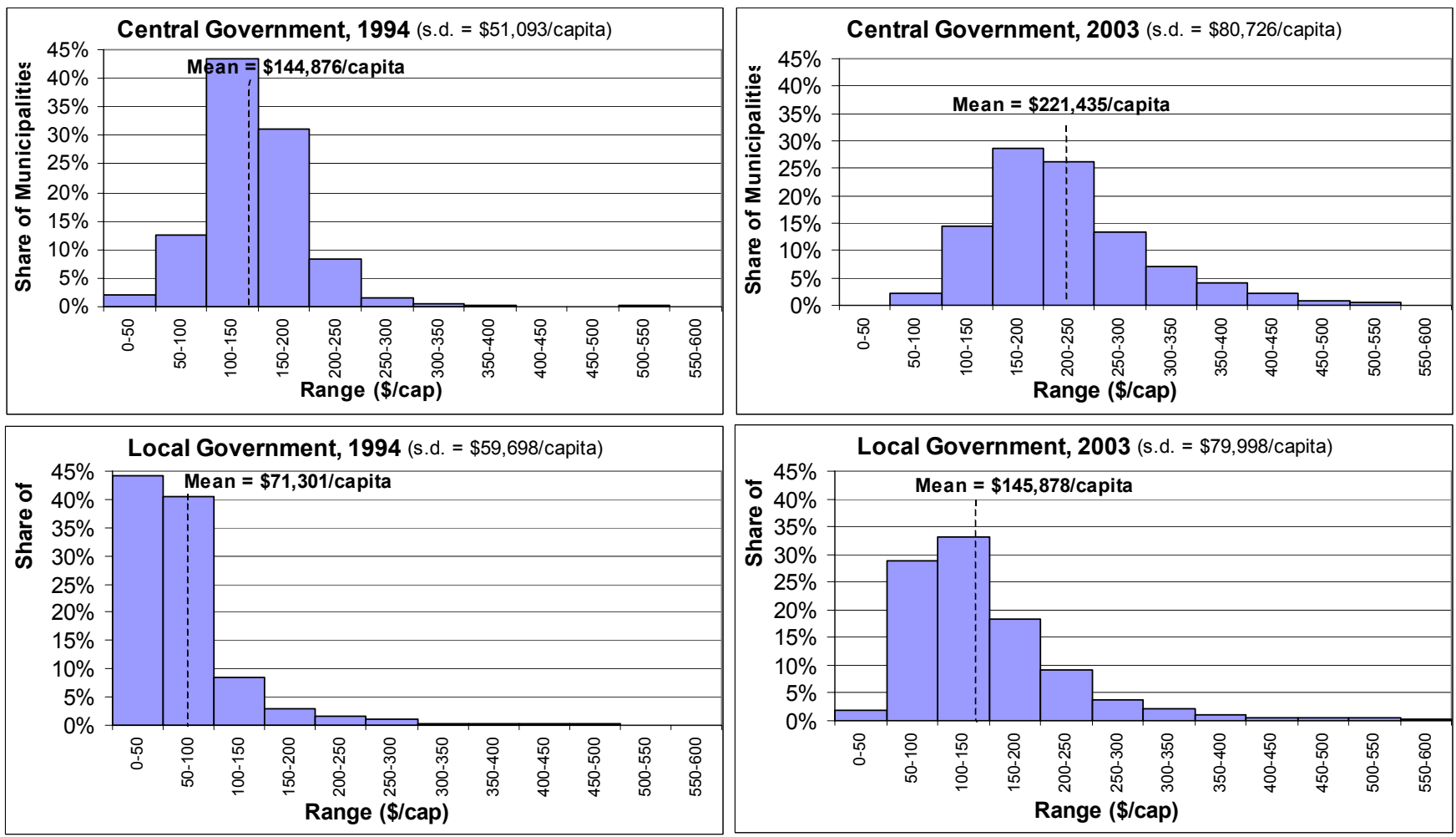

Source: Original calculations; database compiled from official Colombian sources

Lastly, is there any evidence that these broad changes in resource flows affected development outcomes of interest? We focus again on education, and in particular on school attendance figures. Figure 7 shows enrollment data for the period in question, for both public and private schools, with enrollment in 1994 indexed to 1 . At the outset, public and private enrollment trends are quite similar. After 1996 an increasing gap opens up between them, although they continue to trend up and down in parallel. After 
1999, however, the slopes diverge, leading to a large gap between the two educational systems. Decentralization seems to have been good for Colombian education, raising school enrollment by 20 percent. The concentration of improvement in public schools, where enrollment increased 30 percent while the private system's fell seven percent, suggests that local governments were able to run schools and promote attendance better than central government had before. But such descriptive evidence is far from conclusive. We return to this question with much more rigor in section 5. But before we can do so, we must lay out our methodology.

\section{Figure 7: Decentralization and School Enrollment}

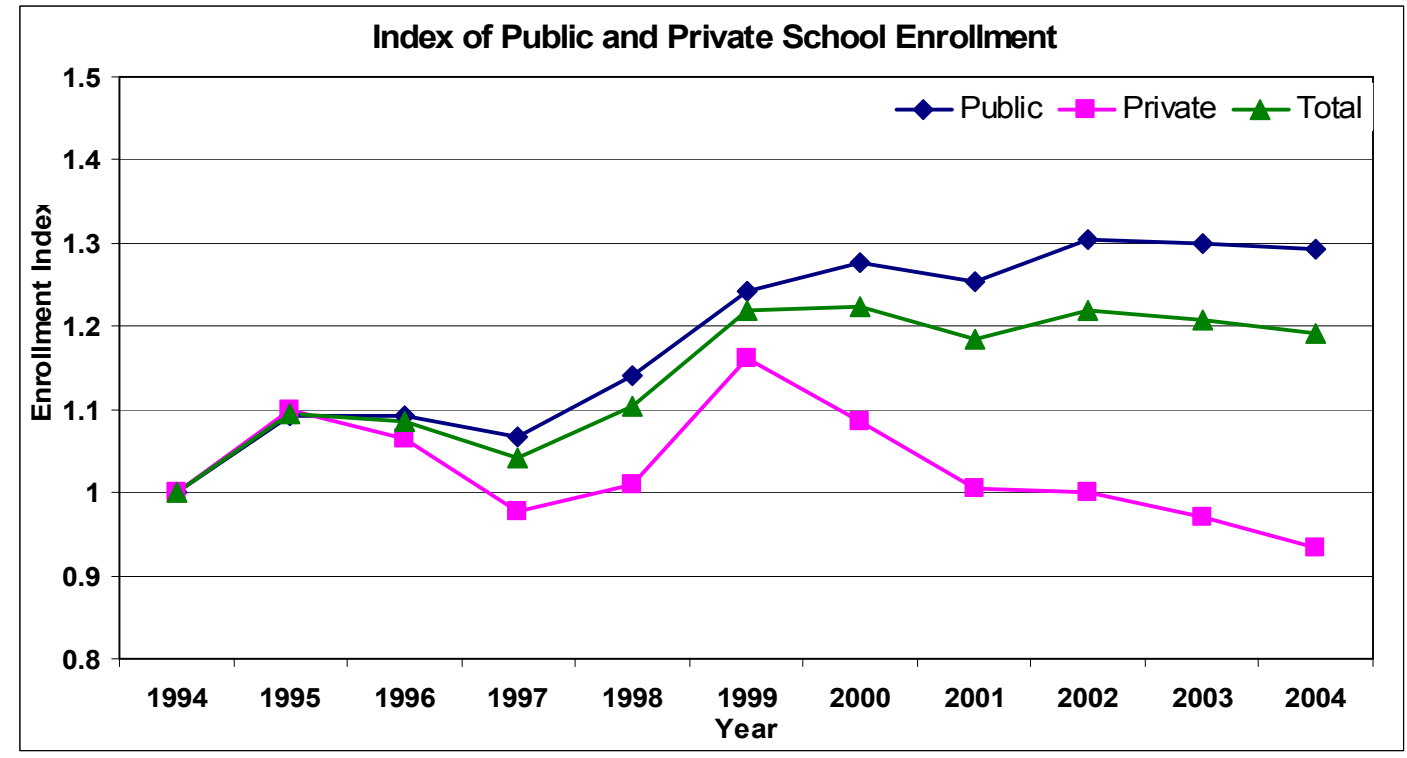

Source: Original calculations; database compiled from official Colombian sources

\section{METHODOLOGY}

The evidence thus far suggests that decentralization changed Bolivia's and Colombia's public investment patterns in important ways, and may have improved the targeting of public services as well. But stronger evidence is needed if we are to reach 
firm conclusions. Ideally such a comparison would be based on very similar regression equations for both countries. But the different nature of reform in the two countries $-\mathrm{a}$ massive decentralization shock versus more gradual reform - demands that we use different empirical approaches, even though we ask similar questions of each case. In addition, there is simply more and higher-quality data available for Colombia, which allows us to push the analysis further into the realm of public sector outputs. Hence for Colombia we investigate decentralization's effect on the number of children attending public schools. For Bolivia, the data restricts us to examining whether decentralization made investment allocations more responsive to local need. ${ }^{11}$ Due to space constraints, we present detailed results for education only. It is worth mentioning that we have quite similar results to those presented here for health and water and sanitation in both countries, and for urban development and agriculture in Bolivia as well.

\section{(a) Bolivia}

Bolivia decentralized on July $1^{\text {st }}, 1994$; two-thirds of the municipalities involved did not exist before 1994. Hence we need an empirical strategy that can cope with the generalized shock of Bolivian reform. Our aim is to test whether decentralization made public investment more responsive to local needs. This can be separated into two questions: (i) did public sector investment patterns change with decentralization? and if so, (ii) do indicators of need determine that change? Using panel data for the period 1987-1996, we estimate the model

$$
\mathrm{G}_{\mathrm{mt}}=\beta_{1} \alpha_{\mathrm{m}}+\beta_{2} \alpha^{*}{ }_{\mathrm{m}}+\beta_{3} \delta_{\mathrm{t}}+\varepsilon_{\mathrm{mt}}
$$

where $\alpha_{\mathrm{m}}$ and $\delta_{\mathrm{t}}$ are vectors of state and year dummy variables, and $\alpha^{*}{ }_{\mathrm{m}}$ is the product of $\alpha_{\mathrm{m}}$ and a decentralization dummy variable which takes the values 0 before 1994 and 1 after. $^{12}$ Investment patterns are thus decomposed into three terms: a year effect, $\delta_{t}$, which 
captures year shocks and time-specific characteristics; a state effect, $\alpha_{\mathrm{m}}$, which captures all of the characteristics of a state fixed in time; and a decentralization-interacted state effect, $\alpha^{*}{ }_{m}$, which captures state-specific characteristics that begin in 1994. By construction, this last term captures the effects of local government, local civic associations and other local institutions that emerged after reform, and locally-specific social and political factors more generally. Any systemic changes in Bolivia's politics or economy that affect all municipalities similarly, such as a national policy initiative or an external shock, will be captured by the year term, $\delta_{\mathrm{t}}$.

We then perform three tests:

1. $\beta_{1}=\beta_{2}$ This simple t-test determines whether $\alpha_{\mathrm{m}}$ and $\alpha^{*}{ }_{\mathrm{m}}$ (national means) are significantly different for each sector. Significance implies that decentralization changed national investment patterns through the actions of local governments.

2. $\beta_{1 \mathrm{~m}}=\beta_{2 \mathrm{~m}}$ This F-test determines whether $\alpha_{\mathrm{m}}$ and $\alpha^{*}{ }_{\mathrm{m}}$ are different municipality by municipality. A significant F-test implies that decentralization changed local investment patterns in a particular municipality. Significance in many municipalities constitutes stronger evidence that decentralization changed national investment patterns in that sector.

3. Lastly, we place the differences in state dummy coefficients on the LHS and estimate the model

$$
\beta_{2}-\beta_{1}=\zeta \mathbf{S}_{\mathrm{m}}+\eta \mathbf{Z}_{\mathrm{m}}+\gamma \mathbf{P}_{\mathrm{m}}+\varepsilon_{\mathrm{m}}
$$

where $\mathbf{S}$ is a vector of the existing stock of public services at an initial period; $\mathbf{Z}$ is a vector of measures of civil institutions, private sector dynamism, and municipal project planning procedures, all local and only relevant after decentralization; and $\mathbf{P}$ is a vector of political participation and the prevalence of left-wing ideology. All are 
indexed by municipality $\mathrm{m}$. This approach isolates the changes in investment patterns resulting from decentralization, and then examines its determinants.

By construction $\beta_{2}-\beta_{1}$ should be unrelated to all factors which remain constant between the two periods, and thus we omit socio-economic, regional and other variables that do not change with decentralization. We assume that the variables in $\mathbf{Z}$ and $\mathbf{S}$ are constant over the period in question. ${ }^{13}$ We report results for tests 1 and 2 for 10 sectors (as defined by Bolivia's finance ministry). We report results from test 3 only for education.

There are literally dozens of variables that might be included in the $\mathbf{Z}$ vector, covering such specific items as municipal employee characteristics and decision-making processes, and how investment projects are planned and written into the local budget. ${ }^{14}$ We use principal component analysis to reduce very specific $\mathbf{Z}$-type variables into more useful indicators that are conceptually coherent and manageable. We construct three principal component variables characterized as follows:

\begin{tabular}{|c|c|c|}
\hline Variable & $\begin{array}{l}\text { PCV } \\
\text { No. }\end{array}$ & Interpretation: Variable increases in... \\
\hline Private sector & 1 & Dynamism of the local private sector \\
\hline Project planning & 1 & $\begin{array}{l}\text { Informed project planning that follows open and } \\
\text { consensual procedures }\end{array}$ \\
\hline Civil institutions & 1 & Strength of local civil institutions and organizations \\
\hline
\end{tabular}

This empirical strategy follows Faguet's (2004) treatment of decentralization in Bolivia.

The main variable of interest in test 3 is $\mathbf{S}$, which we interpret as a district's need for additional public investment. We use three measures of illiteracy and literacy rates, plus the existence of a functioning local education authority, as rough indicators of the level of education provision in each municipality. Assuming that the marginal utility of a 
public service falls as the level of that service rises, we interpret high illiteracy (low literacy) rates as indicative of a greater need for additional education investment. The existence of a properly constituted local education authority similarly indicates higher provision, and hence lower need. We thus expect coefficient $\zeta$ to be positive when illiteracy rates are used, and negative when the literacy rate is used. This would imply that decentralization led government to invest more heavily in places where existing levels of education were low. A positive coefficient, by contrast, would imply that decentralization accentuated educational disparities, as better provided municipalities received higher levels of additional investment.

The variables in $\mathbf{Z}$ are not only controls. Their coefficients, $\eta$, are of interest insofar as they help explain the mechanisms by which local government is more (or less) responsive than central government to real local need. The case put forward by political scientists ${ }^{15}$ for local government's superior assessment of local preferences includes greater sensitivity to grass-roots demand, greater accessibility of local lobby groups to local government, and greater political accountability to the local populace. Some of the ways in which this can happen include the use of open, informed planning techniques, and the existence of private sector and civic organizations that are strong and dynamic. Remember that such local factors were not relevant to central decision-making, which occurred at the center. Variables $\mathbf{P}$ capture another local feature that changed significantly with decentralization: the power of relatively small groups of voters to influence policy makers' decisions via local elections. We expect districts where electoral participation increased with decentralization to be less subject to the sort of capture that Bardhan and Mookherjee (2000) analyze. And left-wing parties' share of the 
vote captures an underlying local ideological characteristic that should increase education investment independently of need.

\section{(b) Colombia}

Reform in Colombia was more gradual, phased in over a number of years. We can take advantage of this fact to construct for Colombia continuous variables that captures advancing reform, and use panel estimations that incorporate much more information than is possible for Bolivia. And as noted above, the availability of higherquality data further allow us to investigate decentralization's effect on real policy outputs, and not just changes in resource inputs. Section 3 showed that decentralization in Colombia was associated with a marked increase in the number of state-school students. In order to investigate this relationship more rigorously, we estimate the model

$$
\Delta \mathrm{S}_{\mathrm{mt}}=\alpha+\zeta \mathbf{D}_{\mathrm{mt}}+\beta \mathbf{R}_{\mathrm{mt}}+\gamma \mathbf{P}_{\mathrm{mt}}+\delta \mathbf{C}_{\mathrm{mt}}+\varepsilon_{\mathrm{mt}}
$$

where $\Delta \mathrm{S}$ is the year-on-year increase in student enrollment in state schools, $\mathbf{D}$ is a vector of measures of where municipalities lie on the decentralization-centralization continuum, $\mathbf{R}$ is a vector of measures of resource availability (i.e. supply factors) that might independently increase student enrollment, $\mathbf{P}$ is a vector of variables measuring political participation and engagement, and $\mathbf{C}$ is a vector of socio-economic and geographic controls, all indexed by municipality $\mathrm{m}$ and year $\mathrm{t}$.

Our measures of decentralization, $\mathbf{D}$, are based on municipal expenditures in education broken down by source of revenue. They measure different levels of autonomy in municipal decision-making and resource commitment. The first is own resources revenue raised from local taxes and charges - as a share of total expenditure. Such funds have no strings attached, and are at the free disposal of local governments to spend as 
they like. The second variable, Municipal Independence, is a dummy that records which municipalities are "certified", and so receive transfers directly from central government, and not via the departmental (i.e. regional) level. Departments have discretion in how they pass on funds destined for municipal uses, and so certified municipalities are more independent of departmental influence and meddling. Local governments that score higher in these two variables are substantively more decentralized than the rest.

The third variable records the share of total educational expenditure accounted for by central transfers allocated according to poverty indices. ${ }^{16}$ In 2001 , Law 715 changed this allocation mechanism to one based on the number of state school students. Hence the last $\mathbf{D}$ variable, which records central transfers based on student numbers as a share of total expenditure (for the period 2002-04). Municipalities with higher values in these indicators face stronger incentives set by the center, and are thus much more "centralized". The coefficients of these four $\mathbf{D}$ variables, $\zeta_{1} \ldots \zeta_{4}$ are our main interest in this regression. If decentralization drives increases in enrollment, then we would expect $\zeta_{1}$ and $\zeta_{2}$ to be positive, and $\zeta_{3}$ and $\zeta_{4}$ to be negative or insignificant.

Other factors which might affect student enrollment independently of decentralization include how richly a municipality funds its schools, and the general buoyancy of municipal revenues. We control for such effects with $\mathbf{R}$, which includes two terms for municipalities' general expenditure growth (separated into the periods before and after Law 715), a term for per capita expenditure on education, and one for the student-teacher ratio.

Political controls $\mathbf{P}$ include overall turnout and the mayor's electoral support, again separated into two periods before and after the 2001 law; dummy variables for mayors from the Liberal or Conservative parties; and the share of total municipal 
personnel who are university graduates, as a measure of local government's institutional capacity. Lastly, the variables in $\mathbf{C}$ control for municipal size, wealth, inequality, unemployment, and what region it is in, as well as the 1999 recession. We also include measures of a municipality's displaced population, separated between those that receive migratory flows and those that expel them, as rough proxies for how much a locality has been impacted by Colombia's armed conflict. Two final terms, the gross enrollment rate and the proportion of the school-age population attending private education, capture level effects and complementarities between public and private enrollment.

\section{DECENTRALIZATION'S EFFECTS - MORE RIGOROUS EVIDENCE}

This section lays out rigorous econometric evidence that decentralization made public investment flows more responsive to real local needs in Bolivia, and led to substantive improvements in service delivery in Colombia. We present econometric models of decentralization's effects on education investment that cover the universe of Bolivian municipalities and over $85 \%$ of Colombian municipalities.

\section{(a) Bolivia}

Figure 8 shows the results for tests 1 and 2. Using national mean values, the null hypothesis, $\beta_{1}=\beta_{2}$, can be rejected for eight of the 10 sectors tested. Only in health and energy did decentralization appear to make no difference to public investment patterns. Test 2 shows the number of municipalities where we can reject the hypothesis $\beta_{1 \mathrm{~m}}=\beta_{2 \mathrm{~m}}$. Five sectors pass this more demanding test: education, water \& sanitation, agriculture, 
urban development and water management. In three sectors, $\beta_{1} \neq \beta_{2}$ with high levels of confidence when national means are used, whereas using local values, $\beta_{1 \mathrm{~m}}=\beta_{2 \mathrm{~m}}$ almost everywhere. This combination of results implies that reform led to very large shifts in investment flows in a small number of municipalities, and insignificant changes everywhere else.

\begin{tabular}{|c|c|c|c|c|c|}
\hline \multirow[b]{2}{*}{ Sector } & \multicolumn{3}{|c|}{$\begin{array}{c}\text { Test } 1 \\
\text { National Means }\end{array}$} & \multicolumn{2}{|c|}{\begin{tabular}{|l}
\multicolumn{1}{c}{ Test 2} \\
Individual Municipality \\
Tests Significant, by
\end{tabular}} \\
\hline & $\beta_{2}-\beta_{1}$ & t-statistic & P Value & Number & Percent \\
\hline Education & 0.01558 & 22.798 & 0.0000 & 209 & $71 \%$ \\
\hline Water \& Sanitation & -0.01548 & -17.343 & 0.0000 & 224 & $76 \%$ \\
\hline Agriculture & -0.01402 & -8.667 & 0.0000 & 65 & $22 \%$ \\
\hline Urban Development & 0.00484 & 5.324 & 0.0000 & 107 & $36 \%$ \\
\hline Water Management & 0.00107 & 2.932 & 0.0034 & 105 & $36 \%$ \\
\hline Transport & -0.10616 & -5.967 & 0.0000 & 29 & $10 \%$ \\
\hline Communication & -0.00246 & -4.011 & 0.0001 & 7 & $2 \%$ \\
\hline Industry \& Tourism & -0.00171 & -3.768 & 0.0002 & 7 & $2 \%$ \\
\hline Health & -0.00117 & -1.540 & 0.1238 & 49 & $17 \%$ \\
\hline Energy & -0.00475 & -1.281 & 0.2004 & 7 & $2 \%$ \\
\hline
\end{tabular}

\section{Figure 8: Did decentralization change Bolivian investment patterns?}

So decentralization did change national investment patterns, and this change was strongest in education, water, urban development and agriculture. Section 3 showed that education's share of local investment rose impressively after decentralization, and test 1 concurs. Was this rise a function of local educational need? Test 3 explores this question by investigating the determinants of the difference in state dummy variables, $\beta_{2}-\beta_{1}$, equivalent to the investment increase attributable to decentralization (see figure 9). 


\begin{tabular}{|c|c|c|c|c|}
\hline \multirow[b]{2}{*}{ Independent Variable } & \multicolumn{4}{|c|}{ Model } \\
\hline & 1 & 2 & 3 & 4 \\
\hline Illiteracy Rate (Adult) & $\begin{array}{l}0.00017 * * * \\
(2.910)\end{array}$ & & & $\begin{array}{l}0.0001637^{* *} \\
(2.020)\end{array}$ \\
\hline Illiteracy Rate (Over-6) & & $\begin{array}{l}0.0001838 * * \\
\quad(2.500)\end{array}$ & & \\
\hline Literacy Rate & & & $\begin{array}{c}-0.000106 * \\
-1.84\end{array}$ & \\
\hline Local Education Authority & $\begin{array}{l}0.0056 \\
(1.420)\end{array}$ & $\begin{array}{c}0.0054333 \\
\quad(1.380)\end{array}$ & $\begin{array}{c}0.005337 \\
(1.360)\end{array}$ & $\begin{array}{c}0.0060453 \\
(1.350)\end{array}$ \\
\hline Civil Institutions PCV1 & $\begin{array}{l}0.00097 * \\
(1.750)\end{array}$ & $\begin{array}{l}0.0010271 * \\
\quad(1.840)\end{array}$ & $\begin{array}{c}0.0010123 * \\
\quad(1.770)\end{array}$ & $\begin{array}{c}0.0009862 \\
(1.540)\end{array}$ \\
\hline Private Sector PCV1 & $\begin{array}{l}-0.00098 * * \\
(-2.470)\end{array}$ & $\begin{array}{l}-0.00106 * * * \\
(-2.690)\end{array}$ & $\begin{array}{c}-0.001211 * * * \\
(-3.000)\end{array}$ & $\begin{array}{c}-0.000851 * * \\
(-2.100)\end{array}$ \\
\hline Project Planning PCV1 & $\begin{array}{r}-0.00054 \\
(-0.920)\end{array}$ & $\begin{array}{r}-0.000548 \\
(-0.930)\end{array}$ & $\begin{array}{r}-0.000488 \\
(-0.830)\end{array}$ & $\begin{array}{r}-0.000537 \\
(-0.910)\end{array}$ \\
\hline $\begin{array}{l}\text { Change in Electoral } \\
\text { Absenteeism (1993-95) }\end{array}$ & & & & $\begin{array}{l}-2.55 \mathrm{E}-05(*) \\
(-1.620)\end{array}$ \\
\hline $\begin{array}{c}\text { Left-Wing Parties Share } \\
\text { of the Vote, } 1995\end{array}$ & & & & $\begin{array}{r}-0.000128 \\
(-0.860)\end{array}$ \\
\hline constant & $\begin{array}{l}0.00758 * \\
(1.810)\end{array}$ & $\begin{array}{l}0.0080641 * \\
\quad(1.820)\end{array}$ & $\begin{array}{l}0.0203711 * * * \\
\quad(3.730)\end{array}$ & $\begin{array}{l}0.0101111 * * * \\
\quad(3.650)\end{array}$ \\
\hline R-squared & 0.0176 & 0.0162 & 0.0136 & 0.021 \\
\hline Prob $>$ F & 0.001 & 0.002 & 0.003 & 0.001 \\
\hline
\end{tabular}

OLS regressions reported with robust standard errors; t-statistics in parentheses

PCV1 $=1$ st pricipal component variable

$*, * *, * * *=$ coefficients significant at the $10 \%, 5 \%$ and $1 \%$ levels

\section{Figure 9: Decentralization's Effect on Education Investment in Bolivia}

Under decentralization, investment rises as illiteracy rises and as literacy falls.

This implies that local governments invested more than central government in education services in places where the stock of education was lower. The existence of a functioning local education authority appears to have no effect. These results are insensitive to different measures of illiteracy, and to different specifications, as figure 9 shows. Hence in a context of rising education investment nationwide, municipalities where education indicators were disproportionately poor made disproportionately large investments in new or improved schooling. Conversely, those where education indicators were unusually good saw increases below the mean, choosing instead to prioritize other 
sectors. ${ }^{17}$ We interpret this as evidence that decentralization made education investment more responsive to real local need than it had been under central government.

Education investment rises where civil institutions are more vigorous, but falls where the private sector is stronger. Both institutional features are examples of local actors that would have had almost no voice under centralized policy making, but whose influence was greatly increased by decentralization. We interpret these results as a sign of local political competition between opposing forces: on one hand grass roots civic support for better education services - i.e. parents worried about their children; and on the other, private firms lobbying for resources to flow to other sectors where they stand to profit more. ${ }^{18}$ Informed, participative project planning methodologies appear to have no effect. Left-wing parties' share of the vote is also insignificant. The change in electoral absenteeism has the expected sign, and is thus consistent with the civil institutions variable, but is only significant at the $11 \%$ level. These results confirm those of Faguet (2004) and extend them with the inclusion of political variables.

\section{(c) Colombia}

Our results from estimating equation (3) appear in figure 10. Models 1 and 2 are panel estimations with and without regional dummies. Because there is a possibility of endogeneity between one of our main variables of interest, own resources as a share of total expenditure, and enrollment growth, model 3 instruments for the former with the log of local tax revenues. Model 4 provides the Tobit estimation of the instrument. A separate test for endogeneity gave a negative result, but we provide the results in 3 and 4 anyway for the sake of completeness. 
Dependent Variable: Increase in Student Enrollment in Public Schools

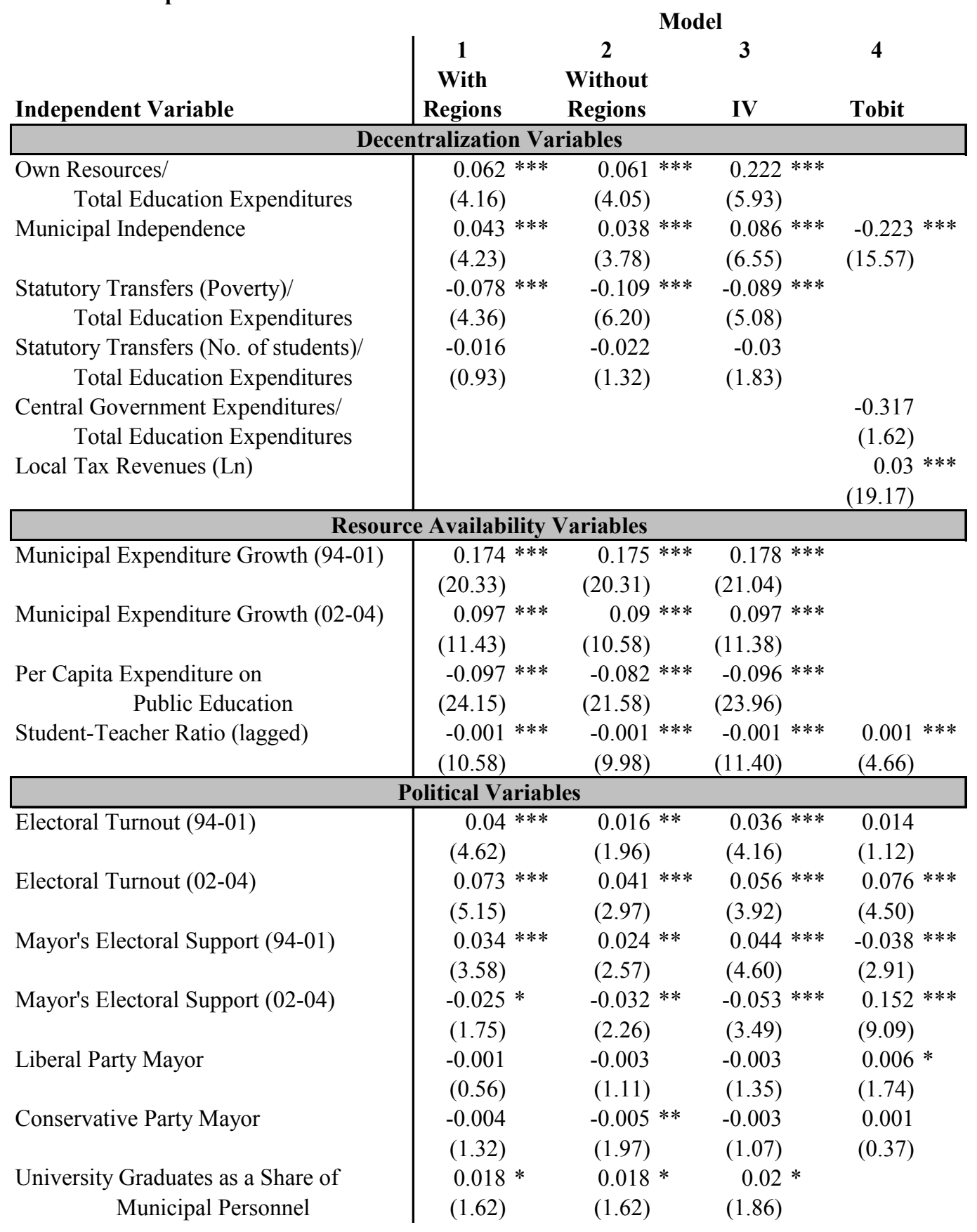




\begin{tabular}{|c|c|c|c|c|}
\hline \multicolumn{5}{|c|}{ Socioeconomic and Regional Variables } \\
\hline Population (Ln) & $\begin{array}{l}-0.016^{* * *} \\
(9.65)\end{array}$ & $\begin{array}{l}-0.014 * * * \\
(9.00)\end{array}$ & $\begin{array}{l}-0.019 * * * \\
(11.03)\end{array}$ & $\begin{array}{l}0.009 * * * \\
(5.19)\end{array}$ \\
\hline Gini Coefficient & $\begin{array}{l}-0.018 * * \\
(2.24)\end{array}$ & $\begin{array}{l}-0.033 * * * \\
(4.16)\end{array}$ & $\begin{array}{l}-0.028 * * * \\
(3.35)\end{array}$ & $\begin{array}{l}0.001 \\
(0.13)\end{array}$ \\
\hline Unsatisfied Basic Needs & $\begin{array}{l}0.00035 * * * \\
\quad(6.18)\end{array}$ & $\begin{array}{l}0.00046 * * * \\
\quad(9.11)\end{array}$ & $\begin{array}{l}0.0005 * * * \\
(7.97)\end{array}$ & $\begin{array}{r}0.0014 \\
(0.39)\end{array}$ \\
\hline $\begin{array}{c}\text { Displaced Population, Receiving } \\
\text { Municipalities }\end{array}$ & $\begin{array}{r}-0.042 \\
(0.33)\end{array}$ & $\begin{array}{r}-0.075 \\
(0.57)\end{array}$ & $\begin{array}{r}-0.051 \\
(0.40)\end{array}$ & \\
\hline $\begin{array}{c}\text { Displaced Population, Expelling } \\
\text { Municipalities }\end{array}$ & $\begin{array}{l}-0.192 * * * \\
(4.04)\end{array}$ & $\begin{array}{l}-0.197 * * * \\
(4.12)\end{array}$ & $\begin{array}{l}-0.191 * * * \\
(4.03)\end{array}$ & \\
\hline Unemployment Rate (Departmental) & $\begin{array}{r}-0.006 \\
(0.46)\end{array}$ & $\begin{array}{r}-0.02 \\
(1.58)\end{array}$ & $\begin{array}{r}-0.002 \\
(0.15)\end{array}$ & $\begin{array}{r}-0.021 \\
(1.23)\end{array}$ \\
\hline 1999 Year Dummy & $\begin{array}{l}0.052 * * * \\
(15.24)\end{array}$ & $\begin{array}{l}0.052 * * * \\
(14.98)\end{array}$ & $\begin{array}{l}0.051 * * * \\
(14.87)\end{array}$ & $\begin{array}{l}0.004 \\
(0.75)\end{array}$ \\
\hline $\begin{array}{l}\text { Gross Enrollment Rate (lagged) } \\
\qquad(\% \text { of School-Age Population) }\end{array}$ & $\begin{array}{l}-0.042 * * * \\
(14.74)\end{array}$ & $\begin{array}{l}-0.035 * * * \\
(12.61)\end{array}$ & $\begin{array}{l}-0.045 * * * \\
(15.52)\end{array}$ & \\
\hline $\begin{array}{l}\text { Private Enrollment Rate (\% of School-Age } \\
\text { Pop. in Private Schools) (Ln, lagged) }\end{array}$ & $\begin{array}{l}0.429 * * * \\
(9.29)\end{array}$ & $\begin{array}{l}0.387 * * * \\
(8.31)\end{array}$ & $\begin{array}{l}0.344^{* * *} \\
(7.01)\end{array}$ & $\begin{array}{l}0.234 * * * \\
(4.04)\end{array}$ \\
\hline Andean Regional Dummy & $\begin{array}{l}-0.105 * * * \\
(3.12)\end{array}$ & & $\begin{array}{l}-0.111 * * * \\
(3.34)\end{array}$ & $\begin{array}{l}-0.146 * * * \\
(3.84)\end{array}$ \\
\hline Caribbean Regional Dummy & $\begin{array}{l}-0.123 * * * \\
(3.67)\end{array}$ & & $\begin{array}{l}-0.124 * * * \\
(3.72)\end{array}$ & $\begin{array}{l}-0.138 * * * \\
(3.64)\end{array}$ \\
\hline Eastern Regional Dummy & $\begin{array}{l}-0.079 * * \\
(2.35)\end{array}$ & & $\begin{array}{l}-0.086 * * \\
(2.55)\end{array}$ & $\begin{array}{l}-0.094 * * \\
(2.45)\end{array}$ \\
\hline Pacific Regional Dummy & $\begin{array}{l}-0.09 * * * \\
(2.70)\end{array}$ & & $\begin{array}{l}-0.095 * * * \\
(2.84)\end{array}$ & $\begin{array}{l}-0.154 * * * \\
(4.06)\end{array}$ \\
\hline Amazon Regional Dummy & $\begin{array}{r}-0.044 \\
(1.31)\end{array}$ & & $\begin{array}{r}-0.055 \\
(1.62)\end{array}$ & $\begin{array}{l}-0.153 * * * \\
(3.97)\end{array}$ \\
\hline Constant & $\begin{array}{l}1.624 * * * \\
(21.00)\end{array}$ & $\begin{array}{l}1.323 * * * \\
(20.87)\end{array}$ & $\begin{array}{l}1.664 * * * \\
(21.44)\end{array}$ & $\begin{array}{l}0.118 * * \\
(2.46)\end{array}$ \\
\hline Observations & 10291 & 10291 & 10291 & 10295 \\
\hline Number of groups & 1042 & 1042 & 1042 & \\
\hline
\end{tabular}

Panel regressions with robust standard errors; t-statistics in parentheses

Model 3 instruments for own resources; Model 4 is the Tobit estimation of the instrument $*, * *, * * *=$ coefficients significant at the $10 \%, 5 \%$ and $1 \%$ levels

\section{Figure 10: Decentralization's Effect on Public School Enrollment in Colombia}

Both measures of strong decentralization are positive and significant at the $1 \%$ level. Public school enrollment rises and as the share of own resources in total educational expenditures rises, and when municipalities are more independent. By contrast, $\zeta_{3}$ is negative and significant, again at the $1 \%$ level. This implies that where central transfers formed a large part of total expenditures, and hence municipalities faced strong incentives set by the center, public enrollment fell. The fourth $\mathbf{D}$ variable, again of 
relative centralization, is negative but insignificant. ${ }^{19}$ These results are not sensitive to the specifications used, and persist when the own resources variable is instrumented. We interpret this as evidence that decentralization of education has led to improved educational outcomes in Colombia, in the sense of more students attending school. By contrast, in those places where central control persists outcomes have worsened.

Supply-side measures of resources availability are all strongly significant. They show that enrollment increases as expenditure grows, and falls with the student-teacher ratio, as one would expect. Curiously, the per capita expenditure term is also negative. This implies that raising student numbers is not a simple question of increasing the education budget, but rather based on other factors, such as how and where funds are invested.

Amongst our political controls, voter turnout is positive and strongly significant, implying a stronger effect on enrollment in places where voters are engaged and participate in politics. Strong electoral support for the mayor also increases enrollment before 2002, although curiously the sign turns negative thereafter. The ideology/party affiliation of the mayor does not seem to matter, nor does the quality of local government's human resources. Of our socioeconomic and geographic controls, results of interest include the first three coefficients, implying that smaller, poorer, relatively more equal districts saw greater increases in enrollment. Public enrollment also rises with the share of students attending private schools, indicating complementarity between the public and private education systems. This contradicts the impression of substitution between public and private enrollment implied in figure 7. Decentralization appears not to improve public schooling at the expense of private schools, but rather to promote the idea of education more generally. Other control variables capturing the impact of 
Colombia's armed violence, the 1999 recession, level effects, and a district's region are also significant.

\section{CONCLUSIONS}

The experiences of Bolivia and Colombia support some of the central claims in favor of decentralization. In both countries decentralization shifted public investment patterns in important ways, switching resources out of infrastructure and industry, and into primary social services such as education and water \& sanitation. In Bolivia, public investment in education became more responsive to real local needs, rising disproportionately in areas with the worst education indicators. As an implicit targeting strategy this is efficient, and probably served to improve educational outcomes, especially in rural areas. Unfortunately, data constraints to not allow us to test that theory.

But we can for the case of Colombia, and the results are unequivocal: decentralization improved enrollment rates in public schools. In districts where educational finance and policy making were freest of central influence, enrollment increased. In districts where educational finance was still based on centrally-controlled criteria, enrollment fell. Further evidence suggests that this was not the simple result of increasing financing levels, but due instead to the quality of investment that municipalities achieved - to how and where funds were spent. Of course, enrollment is only a proximate educational outcome; deeper outcomes of interest include literacy, numeracy and standardized test results. Current data limitations prevent us from using such variables here. Based on the results above, however, we would expect to see 
improving literacy rates as a result of decentralizing education in the medium to long term.

It is striking that in both countries, the major policy changes identified were driven by the behavior of the smallest, poorest, most rural municipalities. To understand this properly, we must place it in the context of what came before. In Bolivia, central government traditionally ignored small, rural districts, whereas in Colombia the center invested much more equitably prior to reform. In both countries, decentralization empowered the smallest, poorest districts disproportionately, and their collective response altered national investment patterns. But decentralization in Bolivia included a huge fiscal equalization shock, which led to much larger changes in the uses and spatial distribution of national investment than for Colombia.

This underlines an important point that is often ignored: decentralization is not a program, but rather a process that relocates power and resources from officials at the center to others at the periphery. Its effects depend very much on the character of central decision-making - on how the center used its power and resources - before reform began. Even the most transparent, well-meaning local administrations might find it difficult to improve upon the performance of a central government that was effective and wellinformed.

But performance did improve in Bolivia and Colombia, at least in education. In Bolivia public investment became more responsive to local needs, and in Colombia more children went to school. These substantive, localized improvements are at least in part due to the new incentives reform put in place. Before decentralization, central officials stationed beyond national and regional capitals had little reason to concern themselves with local demands. Career success was determined by ministerial fiat unrelated to local 
outcomes in distant districts. Throughout most of each country, ordinary citizens' ordinary concerns were given little attention. Decentralization changed this by creating local authorities beholden to local voters. Nationwide, it put real power over public resources in the hands of ordinary citizens. And it changed the way both countries are run. 


\section{NOTES}

${ }^{1}$ Ellis and Bahiigwa (2003), p.1010.

${ }^{2}$ At the time MNR strategists gleefully predicted such a result. They proved wrong.

3 “'Injertos Tramposos en 'Participación Popular”, Hoy, January 19, 1994; “La Declaratoria de Guerra del Primer Mandatario", La Razon, January 27, 1994; and “Arrogancia Insultante”, Presencia, February 27, 1994 are only three of the many articles which appeared in the Bolivian press documenting popular reaction to the "Damned Law". These are documented in Unidad de Comunicación (1995).

${ }^{4}$ Sánchez et al., 2000, show that central transfers grew from 2\% of GDP in 1990 to almost 7\% in 1997.

${ }^{5}$ Colombia's public accounts classify such items as teachers' and health workers' salaries as investments, and not running costs.

${ }^{6}$ The Frente Nacional (1957-74) quelled La Violencia by sharing out the fruits of power equally between Liberals and Conservatives, and restricting electoral competition to those two parties.

${ }^{7}$ There is no obvious way to go beyond this simple exclusion in distinguishing appropriate from inappropriate local investments, especially when categorized sectorally per above. Most local energy investments by number were rural electricity schemes, for example, while a number of education projects involved attempts to establish tertiary educational institutions.

${ }^{8}$ A hodgepodge, including feasibility studies, technical assistance and emergency relief, that is difficult to categorize.

${ }^{9}$ This point is developed further below.

${ }^{10}$ The last year for which comprehensive data are available.

${ }^{11}$ We believe it is preferable to push the analysis as far as each country's data will allow, as opposed to limiting the Colombian analysis for the sake of symmetry.

${ }^{12}$ Thus $\alpha_{\mathrm{m}}^{*}$ takes the value 0 for all municipalities and all years before 1994, and is identical to $\alpha_{\mathrm{m}}$ for all years from 1994 onwards.

${ }^{13}$ This is reasonable for most of the $\mathbf{Z}$ variables, which tend to change slowly over longer periods of time. It is less reasonable for $\mathbf{S}$. Unfortunately the data leave no choice. 
14 There are, for example, 18 variables concerning the types of capacity-building programs that municipalities received after 1994, and 11 more on programs they may have requested.

${ }^{15}$ See for example Wolman in Bennet (1990).

${ }^{16}$ The proportion of the local population above a predetermined level of unsatisfied basic needs.

${ }^{17}$ The small number of municipalities with significant unspent sums implies that the money was spent elsewhere, not left in the bank.

${ }^{18}$ Our results for urban development - typically big, expensive construction projects - where private sector lobbying is strongly positive, support this interpretation.

${ }^{19}$ Possibly because there is too little data from the short time span in question (2002-04). 


\section{REFERENCES}

Alesina, A., Carrasquilla, A., \& Echavarría, J. J. (2000). "Decentralization in Colombia.” Fedesarrollo Working Paper No. 15. Bogotá: Fedesarrollo.

Andersson, K. (2004). "Who talks with whom? The role of repeated interactions in decentralized forest governance." World Development, 32: 233-249.

Bahiigwa, G., Rigby, D., \& Woodhouse, P. (2005). "Right target, wrong mechanism? Agricultural modernization and poverty reduction in Uganda." World Development, 33: 481-496.

Bardhan, P., \& Mookherjee, D. (2000). "Capture and governance at local and national levels.” American Economic Review Papers and Proceedings, 90: 135-139.

Blair, H. (2000). "Participation and accountability at the periphery: Democratic local governance in six countries." World Development, 28: 21-39.

BOLMUNIS. (2002). Bolivian subnational economic, political and demographic database. London: London School of Economics.

Campbell, T. (2001). The quiet revolution: The rise of political participation and leading cities with decentralization in Latin America and the Caribbean. Pittsburgh: University of Pittsburgh Press.

Casson, A., \& Obidzinski, K. (2002). "From New Order to Regional Autonomy: Shifting Dynamics of "Illegal” Logging in Kalimantan, Indonesia." World Development, 30: 2133-2151.

Ceballos, M., \& Hoyos, D. (2004). “Tendencias del comportamiento electoral y descentralización en los municipios de Colombia, 1988-2000.” Crisis States Programme Working Paper No. 57, London School of Economics.

COLREGION. (2005). Colombian subnational economic, political and demographic database. Bogotá: Universidad de los Andes.

Crook, R. C., \& Sverrisson, A. S. (1999). “To what extent can decentralized forms of government enhance the development of pro-poor policies and improve poverty-alleviation outcomes?" Unpublished manuscript. 
Dunkerley, J. (1984). Rebellion in the veins: Political struggle in Bolivia 1952-82. London: Verso.

Ellis, F., \& Bahiigwa, G. (2003). "Livelihoods and rural poverty reduction in Uganda.” World Development, 31: 997-1013.

Ellis, F., Kutengule, M., \& Nyasulu, A. (2003). "Livelihoods and rural poverty reduction in Malawi." World Development, 31: 1495-1510.

Ellis, F., \& Mdoe, N. (2003). "Livelihoods and rural poverty reduction in Tanzania." World Development, 31: 1367-1384.

Eskeland, G., \& Filmer, D. (2002). “Autonomy, participation, and learning in Argentine schools: Findings and their implications for decentralization.” Working Paper No. 2766. Washington, DC: World Bank.

Faguet, J. P. (2004). "Does decentralization increase responsiveness to local needs? Evidence from Bolivia." Journal of Public Economics, 88: 867-894.

Fiszbein, A. (1997). “The emergence of local capacity: Lessons from Colombia.” World Development, 25: 1029-1043.

Francis, P., \& James, R. (2003). "Balancing rural poverty reduction and citizen participation: The contradictions of Uganda's decentralization program." World Development, 31: 325-337.

Klein, H. (1993). Historia de Bolivia. La Paz: Libreria-Editorial Juventud.

Larson, A. M. (2002). "Natural resources and decentralization in Nicaragua: Are local governments up to the job?" World Development, 30: 17-31.

Manor, J. (1999). The political economy of democratic decentralization. Washington, DC: The World Bank.

Maro, P. S. (1990). “The impact of decentralization on spatial equity and rural development in Tanzania." World Development, 18: 673-693.

Martinez-Vazquez, J., \& McNab, R. (2003). "Fiscal decentralization and economic growth.” World Development, 31: 1597-1616. 
McCarthy, J. (2004). "Changing to gray: Decentralization and the emergence of volatile socio-legal configurations in central Kalimantan, Indonesia.” World Development, 32: 1199-1223.

de Mello, Jr, L. R. (2000). "Fiscal decentralization and intergovernmental fiscal relations: A crosscountry analysis." World Development, 28: 365-380.

Montero, A. P., \& Samuels, D. J. (Eds.). (2004). Decentralization and democracy in Latin America. Notre Dame, IN: University of Notre Dame Press.

Nygren, A. (2005). "Community-based forest management within the context of institutional decentralization in Honduras." World Development, 33: 639-655.

de Oliveira, J. A. P. (2002). "Implementing environmental policies in developing countries through decentralization: The case of protected areas in Bahia, Brazil.” World Development, 30: 17131736.

Olowu, D., \& Wunsch, J. S. (1990). The failure of the centralized state: Institutions and selfgovernance in Africa. Boulder, CO: Westview Press.

Parry, T. R. (1997). “Achieving balance in decentralization: A case study of education decentralization in Chile." World Development, 25: 211-225.

Petro, N. N. (2001). “Creating social capital in Russia: The Novgorod model.” World Development, 29: $229-244$.

Piriou-Sall, S. (1998). “Decentralization and rural development: A review of evidence.” Unpublished manuscript.

Porter, G. (2002). "Living in a walking world: Rural mobility and social equity issues in sub-Saharan Africa." World Development, 30: 285-300.

Prud'homme, R. (1995). “On the dangers of decentralization.” World Bank Research Observer, 10:210-26.

Putnam, R. D. (1993). Making democracy work: Civic traditions in modern Italy. Princeton: Princeton University Press. 
Rodríguez-Posé, A., \& Gill, N. (2004). "Reassessing relations between the centre and the states: The challenge for the Brazilian administration.” Regional Studies, 38: 833-844.

Rondinelli, D. A., Cheema, G. S., \& Nellis, J. (1983). "Decentralization in developing countries: A review of recent experience.” World Bank Staff Working Paper No.581. Washington, DC: World Bank.

Rowland, A. M. (2001). "Population as a determinant of local outcomes under decentralization: Illustrations from small municipalities in Bolivia and Mexico." World Development, 29: 13731389.

Samoff, J. (1990). "Decentralization: The politics of interventionism.” Development and Change, 21:513-30

Secretaría Nacional de Participación Popular, Ministerio de Desarrollo Sostenible y Medio Ambiente. (1994). Ley de Participación Popular, Reglamento de las Organizaciones Territoriales de Base. La Paz.

Semboja, J., \& Therkildsen, O. (1994). "Decentralization, participation and spatial equity in rural Tanzania: A comment." World Development, 22: 807-810.

Shah, A., Thompson, T., \& Zou, H. F. (2004). "The impact of decentralization on service delivery, corruption, fiscal management and growth in developing and emerging market economies: A synthesis of empirical evidence." CESifo DICE Report, 1/2004: 10-14.

Shankar, R., \& Shah, A. (2003). "Bridging the economic divide within countries: A scorecard on the performance of regional policies in reducing regional income disparities." World Development, 31: 1421-1441.

Slater, D. (1989). "Territorial power and the peripheral state: The issue of decentralization." Development and Change, 20:501-31.

Smith, B. C. (1985). Decentralization: The territorial dimension of the state. London: George Allen \& Unwin. 
Smoke, P. (2001). "Fiscal decentralization in developing countries: A review of current concepts and practice.” Democracy, Governance and Human Rights Programme Paper No. 2. Geneva:

\section{UNRISD.}

Sundar, N. (2001). “Is devolution democratization?” World Development, 29: 2007-2023.

Tanzi, V. (1995). "Fiscal federalism and decentralization: A review of some efficiency and macroeconomic aspects.” Annual Bank Conference on Development Economics Paper. Washington, DC: World Bank.

Thun, E. (2004). “Keeping up with the Jones': Decentralization, policy imitation, and industrial development in China." World Development, 32: 1289-1308.

Tuchschneider, D. (1997). World Bank rural development officer. Interview, La Paz, February 14.

Unidad de Comunicación, Secretaría Nacional de Participación Popular. (1995). Debate nacional sobre la ley de participación popular. La Paz: Secretaría Nacional de Participación Popular.

UNDP (United Nations Development Program). (1993). Informe sobre desarrollo humano 1993. Madrid: CIDEAL.

Wallis, J. J., \& W. E. Oates. (1988). "Decentralization in the public sector: An empirical study of state and local government.” In H.S. Rosen (Ed.). Fiscal federalism: Quantitative studies. Chicago: University of Chicago Press.

Wiggins, S., Marfo, K., \& Anchirinah, V. (2004). "Protecting the forest or the people?

Environmental policies and livelihoods in the forest margins of southern Ghana." World Development, 32: 1939-1955.

Woodhouse, P. (2003). “African enclosures: A default mode of development.” World Development, 1705-1720.

World Bank. (1994). World development report: Infrastructure for development. New York: Oxford University Press. 